\title{
GENOME EDITING TOOLS AND ITS POTENTIAL APPLICATIONS IN TRANSLATIONAL MEDICINE- A BRIEF OVERVIEW
}

\author{
Agieshkumar B, Senior Scientist \\ Elanthiraiyan S, Project Trainee \\ Central Inter-Disciplinary Research Facility
}

Sri Balaji Vidyapeeth Mahatma Gandhi Medical College and Research Institute Campus

Pillaiyarkuppam, Puducherry - 607403, India

Email: agiesh.b@gmail.com

Abstract $>$

Recent understandings in the genetic basis of diseases emphasize the need for potential

therapeutic strategies. Latest molecular techniques such as RNA interference, gene

therapy and gene editing that can modify nucleic acids within disease affected tissues

can have great potential for treating genetic disorders. In this context, the present review

summarizes the tools available for human gene editing and advances in research with

reference to CRISPR/Cas9 based human genome editing. This review also discusses

various ethical concerns associated with human gene editing.

\section{Introduction}

Genome-editing is a technique that is applied to target a particular deleterious and disease causing genes in certain genetic disorders ${ }^{1}$. Genome editing of somatic cells alters the non-functional cells into functional cells, is at various clinical stages and is considered a promising area of therapeutic development. On the other hand if the targeted genes are altered at the germinal level the disease causing genes can be entirely rectified and cannot be taken over to the next generation ${ }^{2,3}$. There are several ways by which replacement of the faulty gene with functional gene or repair of the faulty gene are reported in case of gene therapy. Homologous recombination is the generally applied method for introducing any change to specific sequence in the genome called genome targeting4. Later RNA interference (RNAi) has been used to knockdown the function of genes implicated in cancer, age-related macular degeneration etc., which was reviewed in detail ${ }^{5,6}$. Despite promise and recent success, the techniques suffers from certain limitations like RNAi often cannot fully repress the gene expression and is therefore unlikely to provide a benefit for diseases in which complete removal of gene function is necessary for therapy. This limits their utility for a large number of diseases. Similarly the techniques described thus far also possess significant off target effect that may switch out genes that are not targeted and leads to undesired effects. However recently developed genomic editing technologies have the potential to be powerful tools for gene therapy because of their ability to inactivate genes, correct mutated sequences, or insert intact genes with reduced off target activities and thus establishing the desired mutations in more cells in any given experiment. A brief overview of recently developed tools in gene editing, potential clinical applications and its ethical issues are given in the below section.

\section{Overview of genome editing technologies}

The four well described methods of Genome editing technologies with clinical applications are mega nucleases (MNs), zinc finger nucleases (ZFN's) transcription activator-like effector nucleases 
Targeting the error in genome by TALFNs/ZFN

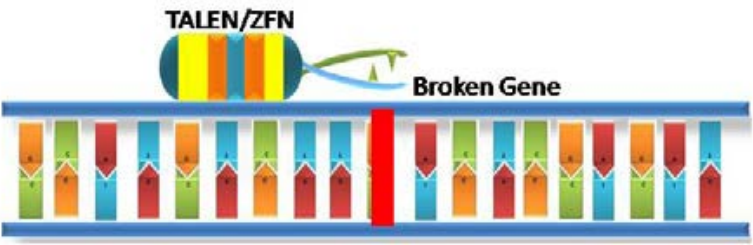

Gene repair by forming DSB and Recombination with normal DNA

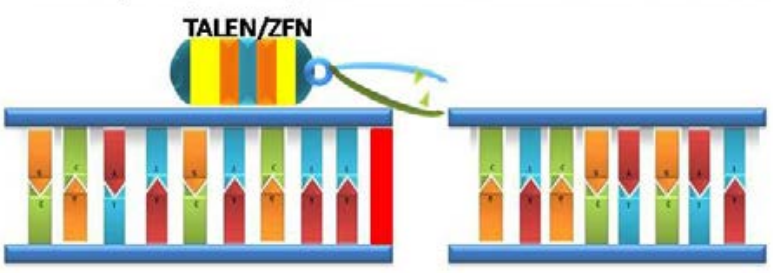

Functional gene after Recombination

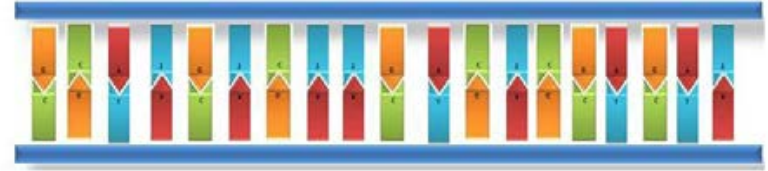

Figure 1. Mechanism of genome editing

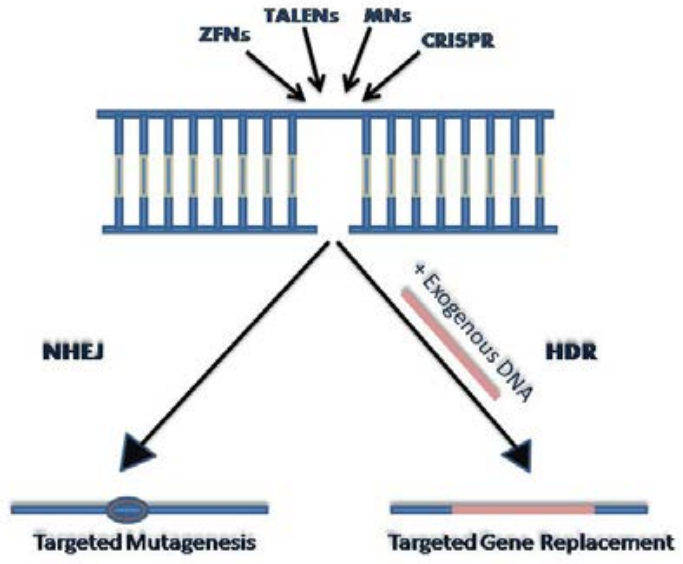

Figure . Mode of gene correction by gene editing

(TALEN's) and the clustered regularly interspaced short palindromic repeat (CRISPR)-associated nuclease Cas97-

${ }^{9}$ These four major tools are currently being explored for the possibility of achieving therapeutic genome editing in diseased cells and tissues, resulting in the removal or correction of deleterious mutations or the insertion of protective mutations ${ }^{10}$. All these genome editing methods works on a common phenomenon in which

Table 1: Comparison of commonly used Gene editing tools in Translational medicine

\begin{tabular}{|c|c|c|c|c|c|}
\hline Tool & Interaction & $\begin{array}{c}\text { DNA } \\
\text { cleavage }\end{array}$ & $\begin{array}{c}\text { Off-Target } \\
\text { effects }\end{array}$ & Multiplexing & $\begin{array}{c}\text { Efficiency } \\
\text { \& Cost } \\
\text { effectiveness }\end{array}$ \\
\hline ZFN & Proteins-DNA & $\begin{array}{c}\text { FokI nuclease } \\
\text { domain }\end{array}$ & $\begin{array}{c}\text { Off-Target } \\
\text { effects have } \\
\text { been reported }\end{array}$ & Very low & $\begin{array}{c}\text { Expensive } \\
\text { \& less efficient }\end{array}$ \\
\hline $\begin{array}{c}\text { Nuclease) } \\
\text { TALEN }\end{array}$ & & FokI nuclease & $\begin{array}{c}\text { Off-target } \\
\text { effects are not } \\
\text { well reported }\end{array}$ & $\begin{array}{c}\text { Used } \\
\text { Occasionally }\end{array}$ & $\begin{array}{c}\text { Moderately } \\
\text { expensive \& } \\
\text { efficient }\end{array}$ \\
\hline $\begin{array}{c}\text { (Transcription } \\
\text { activator-like } \\
\text { effector nuclease) }\end{array}$ & Proteins-DNA & & domain & & \\
\hline $\begin{array}{c}\text { CRISPR/Cas9 } \\
\text { (Clustered } \\
\text { regularly- } \\
\text { interspaced short } \\
\text { palindromic } \\
\text { repeats) }\end{array}$ & RNA-DNA & Cas9 & $\begin{array}{c}\text { Potential off- } \\
\text { target effects } \\
\text { have been } \\
\text { reported }\end{array}$ & High & Cost effective \& \\
highly efficient
\end{tabular}


Table 2: Examples showing the application of gene editing tools in correcting genetic disorders

\begin{tabular}{|c|c|c|c|c|c|}
\hline S. no & Disease & $\begin{array}{l}\text { Genome } \\
\text { editing } \\
\text { tool }\end{array}$ & $\begin{array}{l}\text { Mode of Genome editing } \\
\text { tool }\end{array}$ & Models used & Reference \\
\hline 1 & Cataract & CRISPR & $\begin{array}{l}\text { HDR- Edition of mutation } \\
\text { in mouse zygote }\end{array}$ & Mice model & {$[12]$} \\
\hline 2 & Cystic fibrosis & CRISPR & $\begin{array}{l}\text { HDR-Repair of CFTR in } \\
\text { intestinal stem cell }\end{array}$ & $\begin{array}{l}\text { Primary adult } \\
\text { stem cells }\end{array}$ & [14] \\
\hline 3 & $\begin{array}{l}\text { Duchenne muscular } \\
\text { dystrophy (DMD) }\end{array}$ & $\begin{array}{l}\text { CRISPR } \\
\text { and } \\
\text { TALEN }\end{array}$ & $\begin{array}{l}\text { NHEJ and HDR mediated } \\
\text { gene correction }\end{array}$ & $\begin{array}{c}\text { Cells from DMD } \\
\text { patients,Mice } \\
\text { germline DNA }\end{array}$ & {$[15,16]$} \\
\hline 4 & HIV & $\begin{array}{l}\text { ZFN and } \\
\text { CRISPR }\end{array}$ & NHEJ-mediated repair & $\begin{array}{l}\text { HIV Patient cells, } \\
\text { Pluripotent stem } \\
\text { cells (iPSCs) }\end{array}$ & {$[11,17-19]$} \\
\hline 5 & $\mathrm{HBV}$ & $\begin{array}{l}\text { TALEN } \\
\text { and } \\
\text { CRISPR }\end{array}$ & $\begin{array}{l}\text { NHEJ-mediated depletion } \\
\text { of viral DNA }\end{array}$ & $\begin{array}{l}\text { Mouse model, } \\
\text { Cultured cells }\end{array}$ & {$[20-21]$} \\
\hline 6 & Hemophilia B & ZFN & $\begin{array}{l}\text { HDR-mediated insertion of } \\
\text { correct gene sequence }\end{array}$ & mouse model & {$[12]$} \\
\hline 7 & $\begin{array}{l}\text { Hereditary } \\
\text { tyrosinemia }\end{array}$ & CRISPR & $\begin{array}{l}\text { HDR-mediated correction } \\
\text { of mutation in liver }\end{array}$ & Mouse model & {$[13]$} \\
\hline 8 & $\begin{array}{l}\text { Severe Combined } \\
\text { Immunodeficiency } \\
\text { (SCID) }\end{array}$ & $\mathrm{ZFN}$ & $\begin{array}{l}\text { HDR-mediated insertion of } \\
\text { correct gene sequence }\end{array}$ & $\begin{array}{c}\text { Hematopoietic } \\
\text { stem cells (HSCs) }\end{array}$ & {$[22]$} \\
\hline 9 & $\beta$-thalassemia & $\begin{array}{l}\text { TALEN } \\
\text { and } \\
\text { CRISPR }\end{array}$ & $\begin{array}{l}\text { NHEJ-mediated genome } \\
\text { editing }\end{array}$ & $\begin{array}{c}\text { Induced } \\
\text { pluripotent stem } \\
\text { cells }\end{array}$ & {$[23,24]$} \\
\hline 10 & $\beta$-thalassemia & CRISPR & $\begin{array}{l}\text { NHEJ-mediated genome } \\
\text { editing }\end{array}$ & Human Embryo & {$[25]$} \\
\hline
\end{tabular}

body cells are able to repair any double stranded breaks made to its DNA by endonucleases either by non homologous end joining (NHEJ) or homology-directed repair (HDR). Mostly, the former one is not perfect thereby resulting in deletion or addition of several bases thus mutating the target sequence whereas the latter one uses a homologous sequence that adds specific changes directly on the target site. Thus all the tools mentioned here make use of nucleases to make sitespecific double-stranded breaks (DSB's) in the target genome and the basic working mechanism of TALEN's and ZFN augmenting an error in the genome with a functional copy through homologous recombination is shown in Fig.1. The two different modes of repair (NHEJ and HDR) adapted by the genome editing tools described in this review is depicted in Fig 2.
All the above described genome editing tools are broadly classified into two categories based on their mode of DNA recognition. For instance ZFN, TALEN, and meganucleases achieve specific DNA binding via protein-DNA interactions whereas Cas9 system is targeted to specific DNA sequences with the help of a short RNA guide molecule. All the four nucleases have been reported to yield efficient gene editing in different model organisms and mammalian cells and efforts are now underway to develop these tools as therapeutics ${ }^{11-13}$. Though all the tools work in an efficient manner, a potential advantage of Cas9 is its ability to introduce multiple double strand breaks in the same cell via expression of distinct guide RNAs that drew attention among researchers and currently considered as a best tool for gene editing. Table 1 shows a comparison of ZFN, TALEN and Cas9 in terms of its efficiency and specificity. Table 2 shows some of the diseases in which the tools are being applied to correct the disorder. 


\section{CRISPR-Cas9 System}

CRISPR stands for Clustered Regularly-Interspaced Short Palindromic Repeats discovered in some bacterial DNA $^{26}$. The repeats are used by archaea bacteria for adaptive immunity from invading viruses. Cas9 is a specific endonuclease that can cleave DNA. This CRISPR-Cas9 system is considered a highly specific and convenient tool for gene editing (including gene deletion/gene insertion or gene silencing). The technology is also considered cheap and easy for genetic manipulation. A brief account of the evolution of this technology is given below:

A research team led by Emmanuelle Charpentier and Jennifer Doudna utlilised the CRISPR system from Streptococcus pyrogenes for genome editing for the first time in $2012^{27}$. They generated a single guide RNA (sgRNA) by fusing the crRNA to the tracrRNA, which recruits the Cas9 nuclease to specific genomic locations. The creation of site-specific double-strand breaks by the CRISPR/Cas9 complex then triggers genome editing through 2 different mechanisms. First, in the absence of a homologous DNA template double stranded breaks can be repaired by non-homologous end joining (NHEJ), which is an error-prone process that causes small insertions or deletions. Second, in the presence of a synthetic repair template DSBs can be repaired by homology-directed repair (HDR), which enables the introduction of any desired base-pair changes as described earlier (Fig 1 \&2). The simplicity of this technique drew attention among molecular biologists to use the tool extensively for gene editing and other functional genomic studies though it has not been adequately tested in human. The therapeutic possibility of CRIPSR was first opened by Feng Zhang group, where an engineered novel form of CRISPRCas9 was used to edit the human genome 9 . Based on the speed, efficiency and specificity of CRISPR-Cas9, it is now widely used in the field of cancer biology and considered to be a potential tool for clearing stemness among cancer cell though several of these studies are still in animal models and has not tried in human.

Despite of all these salient features of CRISPR-Cas9 system, it reached the limelight among genetic scientists when the first report came out which described its use in editing "human embryo" 25 . The group studied the ability of the CRISPR/Cas9 system to edit the gene called HBB, which encodes the human ? -globin protein. Mutations in the gene are responsible for ?-thalassaemia, a blood disorder and the team successfully used the system as therapeutic agent to repair the mutant gene from the germ line of the human embryo. Though the system could successfully edit the genome, the study reported off-target mutations introduced by the CRISPR/Cas9 system on other parts of the genome pose a serious threat in using the system as such for clinical applications.

\section{Ethical concerns and limitations of the technology}

The simplicity of creating CRISPR paves way to scientists across the globe to carry out genome editing experiments for therapeutic applications, but working on human embryos or germinal cells poses a serious threat as if any unintended off-target effects introduced by the system during editing could have unpredictable effects to the future generations. Apart from promising clinical applications by treating genetic diseases, the technology may be used for treating unwanted characteristics, for example a report on successful change of the coat color of the rat, open door for inducing pigmentation change in human through genome editing in embryo. This may lead to genetic enhancement of a specific appearance and loss of human diversity and eugenics. Thus Genome editing of the human embryo could hinder the ongoing research that involve gene editing of somatic cells that hold promise for therapeutic development.

An important limitation of the technology is the cost of the gene-editing tools. The cost of the technique is too high for the developing countries to afford and thus may not be implemented effectively all over the world.

\section{Future implications and conclusions}

Though CRISPR-Cas9 genome editing tools holds promise to personalized medicine, translating genome editing tools to the clinic involves major challenges with respect to efficacy and safety. The specificity of the tool should be improved so that the system will not introduce any off-target effect in the genome. Similarly the mode of delivery of the editing tools into the desired cells decides the transient or permanent expression of the gene, thus delivery methods should be properly optimized so that there is no off target activity or immunological responses. Nevertheless, despite all the challenges and the serious ethical issues associated, with improvement in the designing of the tool and careful ethical considerations, CRISPR/Cas9 technology holds immense promises for bringing gene therapy into clinics. 


\section{REFERENCES}

1. Krishan K, Kanchan T. Human genome editing and ethical considerations. Sci Eng Ethics. 2016; 22:597-9.

2. Billings PR, Hubbard R, Newman SA. Human germline gene modification: a dissent. Lancet 1999;353:1873-5.

3. Lanphier E, Urnov F, Haecker SE, Werner M, Smolenski J. Don't edit the human germ line. Nature. 2015; 519: 410-11.

4. Bibikova M, Carroll D, Segal DJ, Trautman JK, Smith J, et al. Stimulation of homologous recombination through targeted cleavage by chimeric nucleases. Mol Cell Biol. 2001; 21:289-97.

5. Vaishnaw AK, Gollob J, Gamba VC, Hutabarat R, Sah D, et al. A status report on RNAi therapeutics. Silence. 2010;1:14.

6. Kay MA. State-of-the-art gene-based therapies: the road ahead. Nature Rev Genet. 2011;12:316-28.

7. Urnov FD, Rebar EJ, Holmes MC, Zhang HS, Gregory PD. Genome editing with engineered zinc finger nucleases. Nature Rev Genet. 2010;11:636-46.

8. Scharenberg AM, Duchateau P, Smith J. Genome engineering with TAL-effector nucleases and alternative modular nuclease technologies. Curr Gene Ther. 2013;13:291-303.

9. Hsu PD, Lander ES, Zhang F. Development and applications of CRISPR Cas9 for genome engineering. Cell. 2014;157:1262-78.

10. Cox DBT, Platt RJ, Zhang F. Therapeutic genome editing: Prospects and challenges. Nat Med. 2015; 21: 121-31.

11. Tebas P, Stein D, Tang WW, Frank I, Wang SQ, et al. Gene editing of CCR5 in autologous CD4 T cells of persons infected with HIV. N Engl J Med. 2014;370:901-10.

12. Li H,Haurigot V, Doyon Y, Li T, Wong SY, et al. In vivo genome editing restores haemostasis in a mouse model of haemophilia. Nature.2011;475:217-22.

13. Yin H, Xue W, Chen S, Bogorad RL, Benedetti E, et al. Genome editing with Cas9 in adult mice corrects a disease mutation and phenotype. Nat. Biotechnol. 2014;32:551-3.

14. Schwank G, Koo BK, Sasselli V, Dekkers JF, Heo I, et al. Functional repair of CFTR by CRISPR/Cas9 in intestinal stem cell organoids of cystic fibrosis patients. Cell stem cell. 2013;13:653-8

15. Ousterout DG, Pinera PP, Thakore PI, Kabadi AM, Brown MT. et al.Reading frame correction by targeted genome editing restores dystrophin expression in cells from Duchenne Muscular Dystrophy patients. Mol Ther.2013;21:1718-30.

16. Long C, McAnally R, Shelton JM, MireaultA, Duby R, etal. Prevention of muscular dystrophy in mice by CRISPR/Cas9-mediated editing of germline DNA. Science. 2014;345:11848.

17. Holt N, Wang J, Kim K, Friedmann G, Wang X et al. Human hematopoietic stem/progenitor cells modified by zinc-finger nucleases targeted to CCR5 control HIV-1 in vivo. Nat. Biotechnol. 2010;28: 839-47.

18. Perez EE, Wang J, Miller J, Jouvenot Y, Kim AK, et al. Establishment of HIV-1 resistance in CD4+ T cells by genome editing using zinc-finger nucleases. Nat. Biotechnol. 2008;26: 808-16.

19. Ye L, Wang J, Beyer Al, Teque F, Cradick TJ, et al. Seamless modification of wild-type induced pluripotent stem cells to the natural CCR5Delta32 mutation confers resistance to HIV infection. Proc Natl Acad Sci U S A. 2014;111:9591-6

20. Lin SR, Yang HC, Kuo YT, Liu CJ, Yang TY, et al. The CRISPR/Cas9 System facilitates clearance of the intrahepatic HBV templates In Vivo. Mol Ther Nucleic Acids. 2014;3:e186.

21. Bloom K, Ely A, Mussolino C, Cathomen T, Arbuthnot P. Inactivation of hepatitis B virus replication in cultured cells and in vivo with engineered transcription activator-like effector nucleases. Mol Ther. 2013; 21:1889-97.

22. Genovese P, Schiroli G, Escobar G, Tomaso T, Firrito C, et al. Targeted genome editing in human repopulating haematopoietic stem cells. Nature.2014; 510:235-40.

23. Ma N, Liao B, Zhang H, Wang L, Shan $Y$ et al. Transcription activator-like effector nuclease (TALEN)-mediated gene correction in integration-free $\beta$-thalassemia induced pluripotent stem cells. J Bio Chem. 2013; 288:34671-79.

24. Xie F, Ye L, Chang JC, Beyer A, Wang J, et al. Seamless gene correction of $\beta$-thalassemia mutations in patient-specific iPSCs using CRISPR/Cas9 and piggy Bac. Genome Res. 2014; 24:1526-33.

25. Liang P, Xu Y, Zhang X, Ding C, Huang R, et al. CRISPR/Cas9-mediated gene editing in human tripronuclear zygotes. Protein Cell. 2015;6:363-72.

26. Wiedenheft B, Sternberg SH, Doudna JA. RNA-guided genetic silencing systems in bacteria and archaea. Nature 2012; 482: 331-8.

27. Jinek M, Chylinski K, Fonfara I, Hauer M, Doudna JA, et al. A programmable dual-RNA-guided DNA endonuclease in adaptive bacterial immunity. Science. $2012 ; 337: 816-21$. 